\title{
Oral rehabilitation in pediatric dentistry: a clinical case report
}

\author{
Reabilitação bucal em Odontopediatria: relato de caso clínico
}

Natalino LOURENÇO NETO'

Cristiane Almeida Baldini CARDOSO'

Ruy César Camargo ABDO'

Salete Moura Bonifácio da SILVA ${ }^{1}$

\begin{abstract}
Despite the emphasis and effort devoted to preventive dentistry, massive coronal destruction caused by dental caries or trauma is still seen in pediatric dentistry practice today. The technical difficulties related to dental treatment are compounded by problems related to the behavior of young patients in these circumstances, which brings the need for a broader understanding of behavior management techniques and certain skills in dealing with patients by dental practitioners, aimed at ensuring the well-being of both patient and dentist during treatment. This case report presents and discusses the scientific rationale for the treatment options adopted, considering the techniques and materials already established for aesthetic rehabilitation of adult patients (such as resins, glass-fiber posts, and glass ionomers), and now employed and adapted for pediatric dental care, that would best suit the clinical situation described. At the end of treatment, the patient achieved full rehabilitation and a restored smile, through the use of modern techniques and materials, while the dental practitioner gained a better understanding of the optimal treatment possibilities and strategies for similar cases.
\end{abstract}

Indexing terms: Mouth rehabilitation. Dental caries. Tooth injuries. Pediatric dentistry.

\section{RESUMO}

Apesar da ênfase e esforço dedicados à Odontologia preventiva, as grandes destruições coronárias causadas por cárie ou traumatismos dentários ainda são hoje problemas que ocorrem na prática clínica da odontopediatria. Além das dificuldades técnicas relacionadas a tais tratamentos, soma-se a isso, os problemas inerentes ao controle da conduta de um paciente muito jovem, o que traz a necessidade de um maior conhecimento de técnicas de manejo comportamental e uma habilidade no trato odontológico por parte do profissional, visando o bemestar de ambos nestas circunstâncias. O relato de caso a seguir tem como objetivo apresentar e discutir o embasamento científico da opção de tratamento adotada, considerando os materiais, pinos de fibra de vidro, ionômeros de vidro, resinas, e as técnicas disponíveis atualmente, ou seja, procedimentos já consagrados na reabilitação estética em adultos, agora aplicados e adaptados à odontologia de bebês, e que melhor solucionariam a situação clínica descrita, visando sua aplicabilidade em clínica. Ao final obtemos um paciente reabilitado, gozando de um tratamento com técnicas e materiais bastante modernos, com seu sorriso restabelecido, e um profissional informado das possibilidades e técnicas mais adequadas para o tratamento de pacientes em situações semelhantes.

Termos de indexação: Reabilitação bucal. Cárie dentária. Traumatismos dentários. Odontopediatria.

\section{INTRODUCTION}

In the 21st century, despite advancements in dental science and clear evidence of the success of preventive measures and minimally invasive procedures, a very young portion of the population still requires extensive oral rehabilitative treatment. Dental caries is known to affect 5 to $20 \%$ of children aged 12 to 36 months ${ }^{1-2}$, usually occurring in the maxillary incisors (the first teeth to erupt). Furthermore, dental trauma is common in this age group, occurring in approximately one-third of all children ${ }^{3}$. These two factors, still commonly observed in pediatric dental practice, account for cases of extensive coronal destruction requiring oral rehabilitation, even in children under the age of 3, which often poses a challenge to the pediatric dentist.

In children, the etiological factors of dental caries are the same as in the general population. However, in younger children, there is the additional factor that teeth are undergoing eruption (which facilitates plaque buildup due to lack of functional occlusion with the antagonist teeth $)^{4}$, made worse by poor or nonexistent oral hygiene.

\footnotetext{
${ }^{1}$ Universidade de São Paulo, Faculdade de Odontologia, Departamento de Ortodontia, Odontopediatria e Saúde Coletiva. Al. Dr. Octávio Pinheiro Brisolla, 9-75, 17012-901, Bauru, SP, Brazil. Correspondência para / Correspondence to: N LOURENÇO NETO. E-mail: <natalusp@yahoo.com.br>.
} 
In very young patients, rehabilitative treatment is challenging due to difficulties inherent to the age of the child, which limit cooperation; to the extent of dental destruction; and to family members' motivations, especially in patients with early loss of deciduous teeth. Therefore, pediatric dentists should be able to plan and implement individualized approaches on a case-by-case basis ${ }^{5}$.

Early loss of the anterior deciduous teeth may cause countless issues. These include psychological impact, which cannot be measured ${ }^{6}$; development of harmful oral habits, interfering with chewing and speech, particularly of the phonemes " $t$ ", "d", "s", "sh", "ch", " $t$ ", and " $d$ "7; and, finally, negative aesthetic effects, including embarrassment when speaking and smiling.

Improvements in restorative materials and techniques have greatly broadened the range of treatment options available for pediatric patients who need both functional and aesthetic repairs.

For rehabilitation of heavily damaged anterior teeth, dentists may use a variety of prefabricated posts that can be combined with PMMA core-forming matrices, preformed stainless steel crowns, or native tooth fragments. These options have distinct aesthetic characteristics, difficulty levels, and costs. In some cases, extraction is indicated; under these circumstances, rehabilitation may be achieved with removable functional space maintainers, which are well-accepted by children ${ }^{8}$.

The indications of resin-modified glass ionomer cement, both to bond posts into the root canal and to build up a core for preparation and composite-resin restoration, using prefabricated forms or matrices, have been discussed ${ }^{9-10}$. Especially in pediatric dental care, this material is often the best choice for such rehabilitation, not least due to its versatility and ability to release fluoride.

In some cases, use of polypropylene crowns with fiber posts appears to be the most appropriate treatment choice, although indirect techniques, based on obtaining impressions and fabricating the restoration on a cast outside of the mouth, have also been indicated ${ }^{11}$.

Therefore, taking into consideration all factors implicated in the selection of optimal restorative material and technique, the dentist should choose the treatment that best suits the patient, respecting the patient's limits of acceptance and cooperation, while maximizing safety and comfort. In addition, treatment should restore both function and aesthetics, as an aesthetic reconstruction will have a positive impact on emotional aspects and, consequently, provide psychological benefit to the child ${ }^{12}$.

\section{CASE REPORT}

M.H.B.M., a 28-month-old boy, returned to the Infant Clinic of Faculdade de Odontologia de Bauru (FOBUSP), where he had previously been treated for dental trauma of \#51, \#52, \#61, and \#62 (Figure 1). The patient now presented with more severe fractures requiring oral rehabilitation, unlike the simple restorations which had sufficed for treatment of the previous injury. According to the mother, the patient had fallen on the floor while playing at home. The other teeth were free of cavities, and the history was noncontributory. Modified periapical and occlusal radiographs of the injured area were obtained (Figure 2).

Clinical and radiographic examination of the patient revealed prior pulpotomy of \#51 and indications for endodontic treatment of the maxillary incisors secondary to the most recent episode of trauma.

We first performed pulpectomy of \#51. This was followed by vital pulpectomy of \#61, \#62, and \#52; the canals were obturated at the same visit. These teeth were then sealed temporarily with resin-modified glass ionomer cement (Vitremer 3M ESPE, Saint Paul, USA), due to its superior sealing properties and for safety reasons, as the patient was still breastfed (Figure 3).

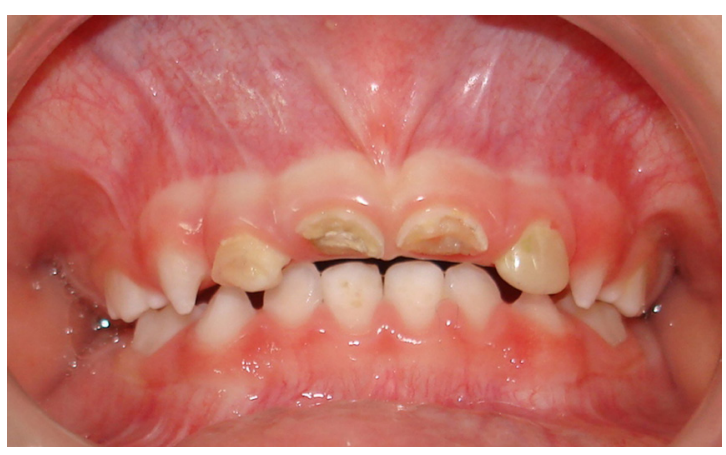

Figure 1. Initial appearance, frontal view.

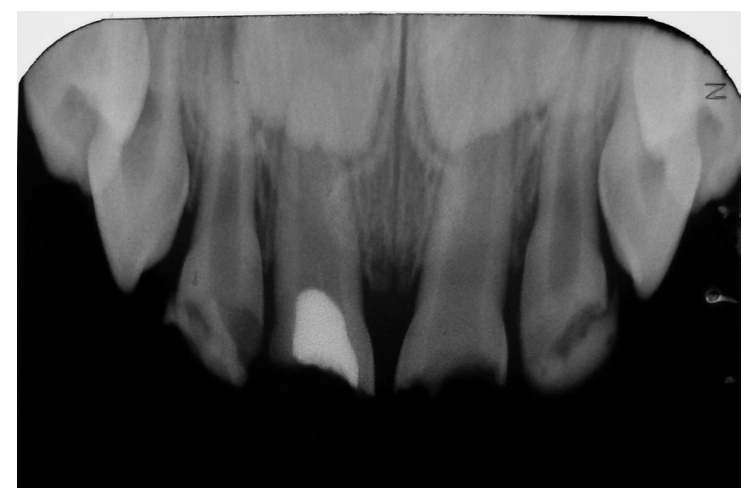

Figure 2. Modified occlusal radiograph after endodontic treatment of \#51, \#52, \#61, and \#62. 


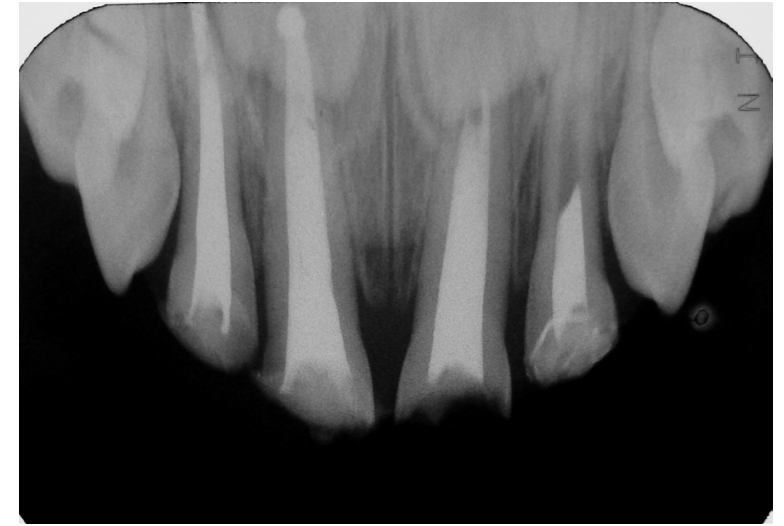

Figure 3. Modified occlusal radiograph showing baseline condition.

The teeth were then rehabilitated with fiberreinforced posts (Reforpost, Angelus, Paraná, Brazil), cemented within the canal, and cellulose acetate stripcrown forms (Ableh, TDV, Santa Catarina, Brazil) filled with composite resin (Filtek Z250, 3M ESPE, Saint Paul, USA).

During subsequent visits, post spaces were created with 1.3-mm \#2 Largo reamers (Dentsply, New York, USA) and endodontic files (Kerr, Maillefer, Switzerland), down to two-thirds of the length of each tooth. The glass-fiber posts were tried in to fit the diameter of the canal with slight resistance. Posts were then cut down to $12.0 \mathrm{~mm}$ for \#51 and \#61 and $10.0 \mathrm{~mm}$ for \#52 and \#62, so as to be 1.0 to $1.5 \mathrm{~mm}$ short of the incisal edge of the coronal restoration. As per manufacturer instructions, the posts and canals were prepared for cementing with Rely-X glass ionomer cement (3M ESPE, Saint Paul, USA). The remaining crown was reconstructed with Vitremer (3M ESPE, Seefeld, Germany/Saint Paul, USA), a resin-modified glass ionomer cement also recommended by the manufacturer for core buildup.

Acetate strip crowns were sized by trial and error, and final cervical adjustments were made to the forms with fine curved scissors as necessary to fit the anatomy of the teeth. Finally, each crown was pierced with an explorer, from the inside out, at the distal incisal angle, for aesthetic reasons. This maneuver creates a vent to facilitate the escape of air and prevent entrapment of bubbles when placing the crown filled with composite resin.

Tooth preparation consisted of minimal wear of the remaining enamel and ionomer cement, leaving a feather-edge cervical finish line, with no taper on the cervical third, so as to provide some resistance to insertion and removal of the crown. A pointed-cone diamond bur (\#2200, KG Sorensen Ind. e Com. Ltda, Barueri, SP, Brazil) was used for this purpose. The prepared tooth was then etched for 15 seconds with $37 \%$ phosphoric acid.

The crown was slowly filled with composite resin while leaving a void in the center, and seated onto the tooth with the bonding agent of choice already applied.

Seating requires a certain amount of pressure and attention to placement in relation to the adjoining teeth. Any excess material is removed with an explorer before polymerization. During this visit, preferably, only gross reductions should be performed with a manual cutting instrument. Aesthetic finishing and final polishing were performed at a subsequent visit, one week later (Figures 4 and 5).

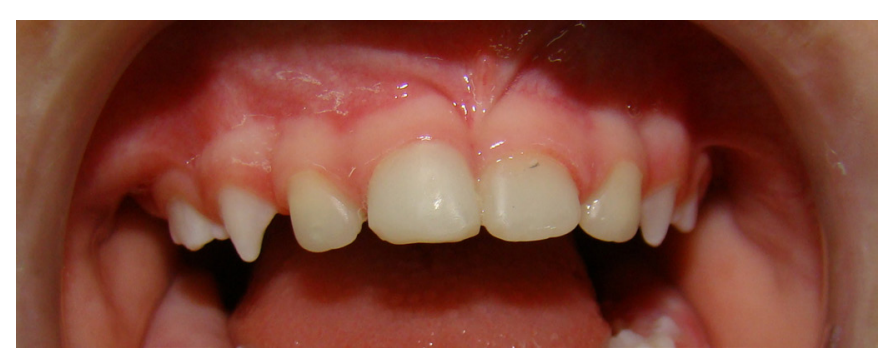

Figure 4. Final appearance, frontal view.

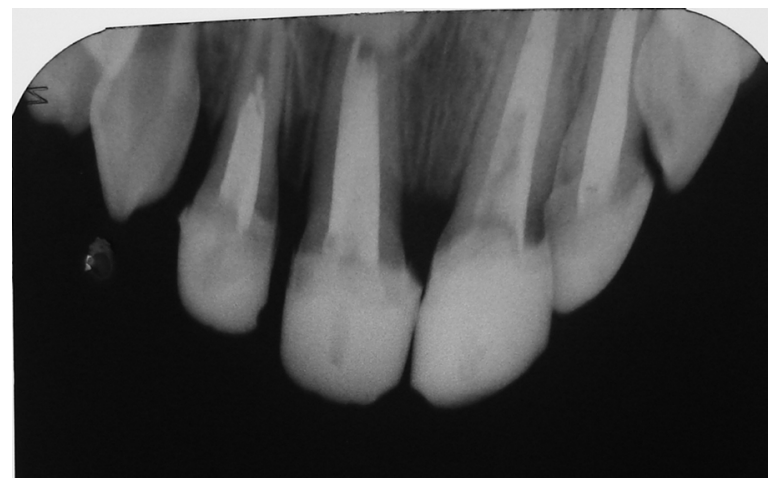

Figure 5. Modified occlusal radiograph showing final condition.

\section{DISCUSSION}

Premature loss of the anterior deciduous teeth due to dental caries or trauma causes a series of oral problems, ranging from disorders of mastication and speech to loss of space. In addition, authors have highlighted the importance of dental aesthetics and presence of the anterior teeth for proper childhood psychological development ${ }^{13}$, which may be influenced by starting school at increasingly early ages and by interaction with other children.

Seger ${ }^{14}$ notes that the support of family members, shows of understanding regarding the child's missing teeth, 
and absence of mocking or teasing help the child accept tooth loss as a normal part of development. Interaction with other children during this transient stage of missing teeth also helps the child accept this as a fact and is a source of emotional comfort.

In the present case, although the patient was not yet attending school, he demonstrated embarrassment when speaking and smiling and frequently asked his family members about his missing teeth. He had probably already noticed the lack of upper lip support, which was clinically visible.

Authors such as Biancalana et al. ${ }^{15}$ have noted that development of slow or slurred speech after loss of teeth due to trauma justifies oral rehabilitation: as many sounds are articulated with the tongue against the palatine surface of the maxillary incisors, inappropriate speech production may occur if these teeth are missing.

The evolution of glass ionomer cement, and its combination with new types of filler particle, have made this the material of choice for many dentists, providing versatility both for bonding and for restoration ${ }^{16}$, which justified its use in the present case. Due to its mechanical and cariostatic properties, resin-modified glass ionomer cement can replace lost dentin, while composite resin, with its broad aesthetic capabilities, can replace lost enamel, thus providing the indication for use of these materials in the present case, for rehabilitation in the aesthetic zone. However, as the affected teeth had lost much of their coronal structure, posts were also required, both to provide additional retention (as noted by Sharaff ${ }^{17}$ and Rocha ${ }^{18}$ ) and to increase the strength of the restorations during chewing.

\section{REFERENCES}

1. Bönecker MJS, Guedes Pinto AC, Walter LRF. Prevalência, distribuição e grau de cárie dentária em crianças de 0 a 36 meses de idade. Rev Assoc Paul Cir Dent. 1997;51(6):535-540.

2. Walter LRF. Cárie em crianças de 0 a 30 meses de idade e sua relação com hábitos alimentares. Enc Bras Odontol. 1987;6(1):129-136

3. Andreasen JO, Ravn JJ. Epidemiology of traumatic dental injuries to primary and permanent teeth in a Danish population sample. Int J Oral Surg. 1972;1(5):235-9.

4. Seale NS, Kendrick AG. A survey of pediatric dentists' management of dental caries in children three years of age or yonger. Pediatr Dent. 2001;23(3):211-6.

5. Mendes FM, De Benedetto MS, del Conte Zardetto CG, Wanderley MT, Correa MS. Resin composite restoration in
Another important factor was the psychological effect of rehabilitation, as made evident by the child's joyful reaction to restoration of the fractured teeth. This reaction was consistent with the behavior reported by Piassi et al. ${ }^{8}$, whereby children become more cheerful and communicative, and with the statement by Seger ${ }^{14}$ that aesthetic "reconstruction" also "rebuilds" emotional aspects.

\section{CONCLUSION}

Several strategies have been proposed for oral rehabilitation of children who have lost teeth due to trauma or early childhood caries. The choice of therapy should be individualized and based on acceptability to each patient and their family. Therefore, dental practitioners should be sensitive to the best interests of their patients by choosing techniques and materials with scientifically proven good performance over time. In the case reported herein, rehabilitation was performed with direct composite restorative materials, so as to restore the form and function of the affected anterior teeth and enable resocialization of the child.

\section{Contributors}

N LOURENÇO NETO, CAB CARDOSO were responsible for the clinical portion of this case and wrote the manuscript. RCC ABDO served as research advisor, was responsible for the supplies employed, provided clinical support, and provided writing assistance. SMB SILVA provided clinical support and writing assistance.

primary anterior teeth using short post technique and strip crows: a case report. Quintessence Int. 2004 Oct;35(9):689-92.

6. Kapur A, Chawla HS, Goyal A, Gaube K. An esthetic point of view in very young children. J Clin Pediatr Dent. 2005 Winter;30(2):99-103.

7. Ngan P, Fields H. Orthodontic diagnosis and treatment planning in the primary dentition. ASDC J Dent Child. 1995 JanFeb;62(1):25-33

8. Piassi E, Volschan B, Louvain M, Damasceno L. Mantenedor de espaço fixo para região anterior na dentição decídua. J Bras Odontop Odontol Bebê. 2000;3(14):273-278.

9. Mandroli PS. Biologic restoration of primary anterior teeth: a case report. J Indian Soc Pedod Prev Dent. 2003;21(3):95-7.

10. Navarro MFL, Pascotto RC. Cimentos de ionômero de vidro: aplicações clínicas em odontologia. São Paulo: Artes Médicas; 1998. p. 179. 
11. Motisuki C, Santos-Pinto L, Giro EM. Restauration of severely decayed, Primary incisors using indirect composite resin restoration thecnique. Int J Paediatr Dent. 2005 Jul;15(4):282-6. doi: 10.1111/j.1365-263X.2005.00645.x

12. Damasceno LM, Marassi CS, Ramos MEB, Souza IPR. Alterações no comportamento infantil decorrente da perda de dentes anteriores: relato de caso. Rev Bras Odontol. 2002;59(3):193196.

13. Bee HL, Mitchell SK. A pessoa em desenvolvimento. São Paulo: Harper \& Row do Brasil; 1984

14. Seger L. Psicologia e Odontologia: uma abordagem integradora. 3a ed. São Paulo: Santos; 1998.

15. Biancalana H. Prótese na clínica de odontopediatria. In: GuedesPinto AC, Correa MSNP, Giglio EM. Odontopediatria clínica. São Paulo: Artes Médicas; 1998. p. 191-230.
16. Garlisi NW. Clinical evaluations: Artglass. Dent Advisor. 1999;16(11).

17. Sharaf AA. The application of fiber core posts in restoring badly destroyed primary incisors. J Clin Pediatr Dent. 2002;26(3):21724.

18. Rocha Rde O, das Neves LT, Marotti NR, Wanderley MT, Corrêa MS. Intracanal reinforcement fiber in pediatric dentistry: a case report. Quintessence Int. 2004;35(4):263-8.

Received on: 21/5/2013

Final version resubmitted on: 7/8/2013

Approved on: 14/2/2014 
